\title{
Corrigendum: Integrative genomic mining for enzyme function to enable engineering of a non-natural biosynthetic pathway
}

Wai Shun Mak, Stephen Tran, Ryan Marcheschi, Steve Bertolani, James Thompson, David Baker, James C. Liao \& Justin B. Siegel

Nature Communications 6:10005 doi: 10.1038/ncomms10005 (2015); Published 24 Nov 2015; Updated 7 Jun 2016

In the original version of this Article the chemical structures of 2-ketoisovaleric acid and isobutanal in Fig. 3a were incorrect. The correct version of Fig. 3 appears below.

a<smiles>CC(C)C(=O)C(=O)O</smiles>

2-Ketoisovaleric acid (IsoC5)

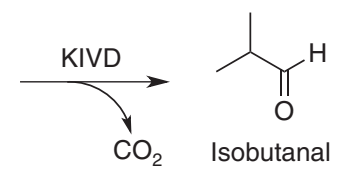

b<smiles>O=C(O)C(=O)O</smiles><smiles>CCCC(=O)C(=O)O</smiles><smiles>CCCCCCC(=O)O</smiles>

Pyruvic acid (C3)

2-Ketovaleric acid (C5)

2-Ketooctanoic acid (C8)

Figure 3

This work is licensed under a Creative Commons Attribution 4.0 International License. The images or other third party material in this article are included in the article's Creative Commons license, unless indicated otherwise in the credit line; if the material is not included under the Creative Commons license, users will need to obtain permission from the license holder to reproduce the material. To view a copy of this license, visit http://creativecommons.org/licenses/by/4.0/ 